A Skeptic Among Scholars 
This page intentionally left blank 


\section{A CENTENNIAL BOOK}

One hundred books

published between 1990 and 1995

bear this special imprint of

the University of California Press.

We have chosen each Centennial Book

as an example of the Press's finest

publishing and bookmaking traditions

as we celebrate the beginning of

our second century.

\section{UNIVERSITY OF CALIFORNIA PRESS}

Founded in 1893 
This page intentionally left blank 
A Skeptic
Among Scholars

August Frugé

on University Publishing

AUGUST FRUGÉ

University of California Press

BERKELEY • LOS ANGELES • LONDON 
This book is a print-on-demand volume. It is manufactured using toner in place of ink. Type and images may be less sharp than the same material seen in traditionally printed University of California Press editions.

As Edwards Brothers, Inc., and The University of California Press celebrate their 100th anniversaries, Edwards Brothers is pleased to provide the paper, printing, and binding for the presentation copies of this commemorative edition to The University of California Press.

The Press also acknowledges the kind provision of the dust jackets for these copies by New England Book Components, Inc.

University of California Press

Berkeley and Los Angeles, California

University of California Press, Ltd.

London, England

(C) 1993 by

The Regents of the University of California

Library of Congress Cataloging-in-Publication Data

Frugé, August, 1909-

A skeptic among scholars : August Frugé on university publishing / August Frugé. p. $\mathrm{cm}$.

"A Centennial book."

Includes bibliographical references and index.

ISBN 0-\$20-07733-4 (alk. paper). — ISBN 0-\$20-08426-8 (alk. paper)

I. University of California Press-History. 2. University presses-California-

Berkeley-History-2oth century. 3. Frugé, August, 1909- . 4. Publishers and publishing-California-Berkeley-Biography. I. Title.

Z473.U623F78 $\quad$ I993

$070.5^{\prime} 94-\mathrm{dc2O}$

93-I3477

CIP

Printed in the United States of America

The paper used in this publication meets the minimum requirements of American National Standard for Information Sciences-Permanence of Paper for Printed Library Materials, ANSI Z39.48-1984. $@$

Title page photo: spiral staircase to the second floor of the Press building on Oxford Street. Photo by David Renick. 
For Susan

Who Knows About These Things 
This page intentionally left blank 